\title{
EFEKTIVITAS LAYANAN INFORMASI DENGAN METODE PROBLEM SOLVING TERHADAP PENINGKATAN KONTROL DIRI SISWA
}

\author{
Romarta Fitri Yana ${ }^{1)}$, Firman ${ }^{2)}$, Yeni Karneli ${ }^{3)}$ \\ Email : firman@konselor.org
}

\begin{abstract}
Today found some students lack the ability to control himself in school. It is seen from the discovery of some students in violation of the norms and rules that have been established in schools deliberately. The aim of thus study reveals : (1) Differences in students' self-control experimental group before and after treatment are given information service with the method of problem solving; (2) Differences in students' selfcontrol before and after control group without treatment given by the information service of problem solving methods; (3) Differences in students' self-control experimental group were given treatment information services with methods of problem solving with students of control group without treatment given by the information service of problem solving methods. This research is a quantitative research approach QuasyExperiment. Population in this research that the students MTsN Lubuk Buaya Padang and samples of this study were selected using simple random sampling technique. The instruments used were questionnaires. (angket). Data were analyzed using the Wilcoxon Signed Ranks Test and Kolmogorov-Smirnov Two Independet Sample with the help of the program Statistical Product and Service Solution (SPSS) versi 20. The result of this research found that: (1) there are significant differences increase student self control before and after the service information by the method of problem solving in the expwrimental group, (2) there is no significant difference in the increase of self-control students in the control group, (3) there are significant differences increase self-control students in the expwerimental group and control group.
\end{abstract}

\section{Keywords: Layanan Informasi, Problem Solving, dan Kontrol Diri}

\section{PENDAHULUAN}

Pendidikan berperan besar dalam menunjang pembangunan bangsa yang merupakan usaha dalam meningkatkan kualitas hidup, kualitas pribadi dan masyarakat yang berlangsung seumur hidup. Pendidikan merupakan suatu usaha untuk membentuk individu menjadi lebih baik dan bermanfaat untuk kedepannya.

Pendidikan Nasional Indonesia bertujuan mencerdaskan kehidupan bangsa dan mengembangkan manusia Indonesia seutuhnya membentuk manusia yang beriman, bertakwa kepada Tuhan Yang Maha Esa dan berbudi luhur, memiliki pengetahuan dan keterampilan, sehat jasmani \& rohani, berkepribadian mantap dan mandiri serta bertanggungjawab kepada masyarakat dan kebangsaan. Hal ini ditegaskan dalam pasal 3 Undang-undang Sistem Pendidikan Nasional No 20 Tahun 2003.

Pencapain tujuan pendidikan itu, siswa harus dapat berkembang secara optimal dengan kemampuan untuk berkreasi, mandiri, bertanggung jawab, dan dapat memecahkan masalah-masalah yang dihadapi. Pendidikan dapat membantu individu bukan hanya dalam mengembangkan kemampuan intelektualnya, tetapi juga dalam mengeembangkan kemampuan mengatasi masalah di dalam dirinya sendiri dan masalah yang ditemuinya dalam interaksinya dengan lingkungan.

Perjalanan hidup setiap individu seringkali menemui berbagai macam masalah. Lepas dari persoalan yang satu muncul persoalan yang lain, demikianlah seterusnya silih berganti persoalan itu timbul. Dan tidak semua individu mampu mengatasi permasalahannya sendiri. Agar mereka dapat mengenali potensi-potensi yang dimiliki, mengembangkannya secara optimal, serta menghadapi masalah yang dihadapi diperlukan bantuan atau bimbingan dari orang lain sehingga mereka dapat berbuat dengan tepat sesuai dengan potensi atau keadaan yang ada pada dirinya.

Pencapaian tujuan pendidikan dapat terealisasi melalui proses belajar yang di dalamnya terdapat sebuah interaksi pendidikan yang melibatkan dua figur yang berbeda pada

\footnotetext{
${ }^{1}$ Romarta Fitri Yana, Jurusan Bimbingan dan Konseling, Fakultas Ilmu Pendidikan Universitas Negeri Padang.

${ }^{2}$ Firman(2), Jurusan Bimbingan dan Konseling, Fakultas Ilmu Pendidikan Universitas Negeri Padang

${ }^{3}$ Yeni Karneli(3), Jurusan Bimbingan dan Konseling, Fakultas Ilmu Pendidikan Universitas Negeri Padang 
suatu situasi. Dimana dua figur tersebut yaitu pendidik (guru) dan peserta didik (siswa) sebagaimana yang dijelaskan Sardiman (dalam Wiwi Sanjaya, 2012:2) bahwa dalam interaksi pendidikan melibatkan tenaga pengajar yang melaksanakan tugas mengajar dan warga belajar yang sedang melaksanakan kegiatan belajar. Pendidik tidak selalu orang yang lebih tua dari peserta didik melainkan seseorang yang dengan sadar sangat dibutuhkan oleh peserta didik untuk memenuhi kebutuhannya. Sedangkan peserta didik adalah individu yang menjadi subjek dari pendidikan tersebut.

Sekolah tidak hanya berfungsi memberikan pengetahuan dalam kegiatan belajar di kelas, tetapi juga dapat mengembangkan keseluruhan kepribadian anak. Oleh karena itu, guru harus mengetahui lebih dari sekedar masalah tentang bagaimana cara mengajar yang efektif. Guru harus dapat membantu siswa dalam mengembangkan seluruh aspek kepribadian dan lingkungannya, selama itu memungkinkan secara profesional. Dalam usaha membantu siswa itu, guru perlu mengetahui konsep, landasan, prosedur dan praktek bimbingan.

Bimbingan dan konseling merupakan suatu rangkaian usaha yang sungguh-sungguh yang dilakukan oleh seorang konselor guna memandirikan klien. Artinya, membantu klien agar dapat melaksanakan kehidupannya secara wajar tanpa mengalami masalah sehingga tercapainya kehidupan efektif sehari-hari.

Secara kelembagaan, bimbingan dan konseling (selanjutnya disingkat BK) adalah bagian dari keseluruhan program pendidikan di sekolah, yang ditujukan untuk membantu dan memfasilitasi peserta didik (siswa) agar mencapai tugas-tugas perkembangannya secara optimal. Oleh sebab itu, keberhasilan ini menjadi tantangan bagi pihak sekolah, khusunya guru pembimbing/guru BK/ konselor.

Prayitno (1999:8) mengemukakan guru BK (bimbingan dan konseling) adalah guru yang ditugaskan untuk melaksanakan kegiatan BK di sekolah. Guru BK yang bertanggung jawab untuk merencanakan dan menindak lanjuti pelayanan BK terhadap peserta didik yang menjadi tanggung jawabnya. Salah satu layanan BK yang dapat diterapkan untuk mengatasi permasalahan siswa di sekolah adalah layanan informasi.

Layanan informasi merupakan layanan kedua dari sepuluh layanan yang ada. Prayitno (2012:50) menjelaskan "layanan informasi berusaha memenuhi kekurangan individu akan informasi yang mereka perlukan. Informasi itu kemudian diolah dan digunakan individu untuk kepentingan hidup dan perkembangannya". Winkel (2007:316) menambahkan "layanan informasi berusaha memenuhi kekurangan informasi yang diperlukan".
Layanan informasi dapat membantu individu terutama peserta didik dalam memenuhi kebutuhan akan informasi yang dibutuhkannya dalam mengatasi permasalahan yang di alaminya, baik masalah pribadi, lingkungan serta masa depan. Namun metode yang digunakan dalam pemberian layanan informasi juga akan mempengaruhi kontrol diri siswa dalam belajar, motivasi belajar serta minat belajar siswa. Pemilihan metode mengajar yang tepat dan sesuai dengan tujuan pembelajaran dapat membantu siswa dalam mencapai hasil belajar yang efektif sesuai dengan tujuan pembelajaran sehingga siswa dapat memahami dan mengambil makna terhadap isi atau materi pembelajaran.

$$
\text { Benny A. Pribadi (2009:42) }
$$

menjelaskan "metode pembelajaran merupakan proses atau prosedur yang digunakan oleh guru atau intruktur untuk mencapai tujuan atau kompetensi". Sejalan dengan itu, Daryanto (2010:45) mengemukakan bahwa "metode mengajar adalah suatu cara atau jalan yang harus dilalui dalam mengajar, mengajar adalah menyajikan bahan pelajaran oleh seseorang kepada orang lain agar orang lain itu menerima, menguasai dan mengembangkannya". Orang yang lain di atas disebut sebagai murid atau siswa, yang dalam proses belajar mengajar agar dapat menerima, menguasai dan lebih-lebih mengembangkan bahan pelajaran itu. Maka cara-cara mengajar serta belajar haruslah setepat-tepatnya dan seefisien serta seefektif mungkin.

Metode mengajar yang kurang baik akan mempengaruhi cara belajar dan pengendalian diri siswa yang tidak baik pula dalam belajar. Salah satu metode mengajar yang dapat digunakan dalam layanan informasi ini adalah metode problem solving yaitu suatu metode yang dapat membantu peserta didik dalam mengentaskan permasalahan yang dihadapinya. Pemilihan metode mengajar yang tepat dan efektif perlu didasarkan pada kesesuaian dengan tugas dan tujuan pembelajaran. Pemilihan metode mengajar yang tepat akan membantu siswa dalam mencapai tujuan pembelajaran yang telah ditetapkan. Pemilihan metode pembelajaran yang tepat dapat digunakan untuk menciptakan kegiatan belajar yang efektif.

Kenyataannya, cara atau metode mengajar yang digunakan guru pembimbing dalam penyampaian layanan informasi kepada siswa berbeda dengan cara yang ditempuh untuk memantapkan siswa dalam menguasai pengetahuan, keterampilan serta sikap belajar yang diinginkan. Metode pembelajaran yang digunakan untuk memotivasi siswa agar mampu menggunakan pengetahuannya dan mampu mengemukakan pendapat atau ide nya dalam memecahkan masalah yang dihadapi ataupun 
untuk menjawab suatu pertanyaan akan berbeda dengan metode yang digunakan untuk tujuan agar siswa mampu berpikir dan mengemukakan pendapatnya sendiri di dalam menghadapi segala persoalan. Agar siswa mampu berpikir secara ilmiah dan mampu mengemukakan pendapatnya dapat digunakan metode problem solving yaitu metode belajar memecahkan masalah.

Nana Sudjana (2011:85) metode problem solving (metode pemecahan masalah) bukan hanya sekedar metode mengajar tetapi juga merupakan suatu metode berpikir, sebab dalam problem solving dapat menggunakan metode-metode lainnya dimulai dengan mencari data sampai kepada menarik kesimpulan. Problem solving yaitu suatu metode dengan cara problem identification untuk ketahap syntesia kemudian dianalisis yaitu pemilahan seluruh masalah sehingga mencapai tahap application selanjutnya komprehension untuk mendapatkan solution dalam penyelesaian masalah tersebut. Problem solving adalah suatu proses mental dan intelektual dalam menemukan masalah dan memecahkan berdasarkan data dan informasi yang akurat, sehingga dapat diambil kesimpulan yang tepat dan cermat.

Problem solving merupakan salah satu metode mengajar yang menuntut keaktifan dan kemampuan berpikir siswa secara ilmiah. Dengan metode problem solving akan menekankan siswa pada penemuan dan pemecahan masalah secara berkelanjutan. Metode ini dapat digunakan untuk membantu meningkatkan kontrol diri siswa, yaitu melalui layanan informasi. Kontrol diri siswa penting untuk ditingkatkan, karena kontrol diri berkaitan dengan suasana hati seseorang.

Pendapat dari Goleman (1997:75) menjelaskan suasana hati adalah inti dari hubungan sosial yang baik. Apabila seseorang terampil dalam menyesuaikan diri dengan suasana hati, maka dia akan mampu mengontrol diri.

Individu yang mampu mengontrol diri dengan baik, tidak akan mudah terpengaruh terhadap segala perubahan yang terjadi dan juga dapat terhindar dari tingkah laku menyimpang. Seperti pada saat temannya mengejek dia, dia akan mampu mengendalikan emosinya untuk tidak marah atau berlaku kasar pada temannya. Hal ini menunjukkan bahwa anak tersebut telah mampu mengendalikan dirinya untuk mengontrol emosinya. Anak-anak yang dilatih dalam mengontrol diri akan mampu bersikap disiplin, tidak mudah tergoda dengan perilaku menyimpang, dan tidak cepat emosi. Sebaliknya anak-anak yang tidak mampu mangontrol diri dia akan kesulitan mendisiplinkan diri, mudah tergoda dengan perilaku menyimpang dan akan cepat emosi (labil).
Kemampuan dalam mengontrol diri membutuhkan sebuah proses. Proses tersebut berasal dari lingkungan keluarga, lingkungan sekolah dan juga lingkungan masyarakat. Di sekolah terutama siswa dilatih untuk mampu mengontrol dirinya sesuai dengan tujuan belajar supaya tercapainya suasana belajar yang efektif dan sesuai dengan yang diharapkan. Kemampuan siswa dalam mengontrol diri juga dilatar belakangi oleh kurangnya informasi siswa terhadap bagaimana cara agar siswa tersebut mampu mengontrol dirinya dengan baik.

Kenyataan yang ada di MTsN Lubuk Buaya Padang yang penulis amati langsung saat melaksanakan PLBK-S, layanan informasi yang ada selama ini kurang efektif. Hal ini terlihat dari informasi-informasi yang diberikan kepada siswa tidak memenuhi kebutuhan informasi yang diperlukan siswa. Begitu juga dengan metode yang digunakan dalam pelaksanaan layanan informasi di sekolah oleh guru BK hanya dengan menggunakan metode ceramah, sehingga mengakibatkan kurang tertariknya siswa dalam mengikuti layanan informasi yang diberikan hal ini juga melatar belakangi rendahnya kontrol diri siswa dalam belajar di MTsN Lubuk Buaya Padang. Sehingga pada saat mengikuti layanan, siswa meribut, keluar kelas, mengganggu teman, mengerjakan kegiatan lain, cabut, menyontek, merokok, bolos dan berjalan-jalan pada saat proses belajar mengajar berlangsung. Rendahnya kontrol diri siswa juga mengakibatkan rendahnya hasil belajar yang diperoleh siswa. Sehingga tujuan untuk mencapai keberhasilan dalam belajar tidak tercapai sesuai yang diharapkan.

Kontrol diri merupakan suatu alat dalam diri sendiri yang berfungsi sebagai kekuatan yang akan menggerakkan diri untuk menjadi pribadi yang sempurna, yaitu pribadi yang mampu mengendalikan segala bentuk kemampuan untuk mewujudkan segala keinginan yang telah direncanakan. Dalam kontrol diri tergantung unsur motivasi yang akan mendorong siswa melaksanakan segala kegiatan yang mendukung tercapainya tujuan yang diinginkan. Tujuan tersebut dapat dicapai apabila tujuan jelas bentuknya dan jelas juga cara untuk mencapainya. Tujuan yang dimaksud ialah mencapai kemandirian siswa dalam mengambil keputusan. Selanjutnya siswa dapat mengembangkan tingkah laku positif dirinya untuk memperoleh tujuan yang lebih sempurna.

Dapat dipahami bahwa dengan adanya kontrol diri akan membuat siswa memiliki peluang yang lebih besar untuk dapat memperoleh keberhasilan, baik keberhasilannya dalam masa depan maupun masa sekarang, karena dalam kontrol diri terkandung aspek bertanggung jawab terhadap tingkah laku, sikap 
yang mandiri, mampu dalam menentukan tujuan sehingga memiliki pandangan yang jelas akan masa depan sendiri. Melalui sikap kontrol diri yang jelas akan dapat mengendalikan hal-hal yang akan menghambatya meraih tujuan yang telah direncanakan dengan jelas.

Berdasarkan penelitian terdahulu oleh Dewi Permata Sari (2011:49) terungkap bahwa kontrol diri siswa di MTsN Lubuk Buaya Padang termasuk pada kategori cukup baik walaupun masih ada remaja yang kurang bisa mengontrol diri di sekolah. Jika dijabarkan didapat bahwa (a) kemampuan dalam mengendalikan tingkah laku cukup baik, (b) kemampuan dalam mengelola informasi cukup baik, (c) dan kemampuan dalam mengontrol keputusan juga cukup baik.

Berdasarkan hasil observasi penulis pada saat melaksanakan Praktek Lapangan Bimbingan dan Konseling di MTsN Lubuk Buaya Padang, ditemukan bahwa beberapa siswa yang tidak mampu mengontrol dirinya dengan baik sehingga siswa terlibat dalam perilaku-perilaku menyimpang di sekolah terutama pada saat belajar, seperti: siswa sering datang terlambat, tidak mematuhi peraturan sekolah, cabut pada jam pelajaran, bolos sekolah, menyontek, merokok di sekitar lingkungan sekolah, berkata-kata kotor dan meribut pada saat proses pembelajaran berlangsung.

Kesimpulan di atas dapat dilihat bahwa kontrol diri merupakan aspek penting yang harus dimiliki oleh setiap siswa. Siswa diharapkan untuk memiliki keterampilan untuk mengatur diri sendiri khususnya dalam belajar. Namun kenyataan di lapangan siswa tidak memiliki keterampilan dalam mengatur dan mengontrol diri dalam menentukan tujuan sebelum proses belajar, mengontrol diri untuk berperilaku positif dan tidak terlibat pada perilaku menyimpang. Untuk itu perlunya peningkatan kontrol diri siswa melalui layanan informasi dengan memanfaatkan metode problem solving agar siswa dapat berhasil dalam belajar dan terhindar dari perilaku-perilaku yang tidak diharapkan serta siswa mampu memecahkan permasalahan yang dihadapinya.

Kondisi yang ditemukan di lapangan peran guru bimbingan dan konseling disini sangatlah penting untuk membantu siswa meningkatkan kontrol dirinya, sehingga siswa dapat berhasil dalam belajar dan menggapai citacita sesuai dengan potensi serta bakat dan minatnya di masa depan.

Sebagai tindak lanjut dari permasalahan ini, penulis menggunakan layanan informasi dengan metode problem solving (pemecahan masalah) untuk meningkatkan kontrol diri siswa, yaitu menekankan pada permasalahan dalam belajar yang bervariasi. Semua materi dan metode tersebut dipresentasikan lewat berbagai pengalaman belajar secara terpadu dalam bentuk layanan informasi, dan berusaha menekankan pada proses berfikir rasional dari siswa, yang dihubungkan dengan kontrol diri siswa.

Berdasarkan uraian dan permasalahan tersebut, guru BK berperan untuk menerapkan layanan bimbingan dan konseling sesuai dengan Pola BK 17 plus. Salah satu layanan yang membimbing siswa untuk dapat meningkatkan kontrol diri siswa adalah melalui layanan informasi dengan metode problem solving.

\section{METODE PENELITIAN}

Penelitian ini merupakan penelitian eksperimen yang menguji hipotesis yang menguji hubungan sebab akibat diantara variabel yng diteliti. Subjek penelitian meliputi siswa kelas VII MTsN Lubuk Buaya Padang yang terdiri dari 25 orang siswa yang akan dijadikan sebagai subyek penelitian pada kelompok eksperimen dan 25 orang siswa pada kelompok kontrol. Instrumen yang digunakan adalah angket dengan lima alternatif jawaban yaitu Selalu, Sering, Kadang-kadang, Jarang dan Tidak Pernah. Teknik analisis data menggunakan presentase (Anas Sudjono, 2009: 318) dengan rumus sebagai berikut:

$$
\text { Mutu }=\frac{\text { shor Ferpianan }}{\text { sfoo rdeal }} 100
$$

Selanjutnya untuk melihat deskripsi data hasil pretest dan posttest digunakan teknik statistik yaitu dengan mencari skor mean (ratarata), standar deviasi, range, skor minimum dan skor maksimum. Menurut Tulus Winarsunu (2002: 59) rumus- rumus tersebut adalah:

1. Mean, yaitu $\mathrm{M}=\frac{\Sigma \mathrm{fx}}{\mathrm{N}}$

2. Standar Deviasi, yaitu $\mathrm{SD}=$

$$
\sqrt{\left(\frac{\sum \mathrm{fx}^{\mathrm{N}}}{\mathrm{N}}\right)-\left(\frac{\sum \mathrm{NX}}{\mathrm{N}}\right)^{2}}
$$

3. $\quad$ Range, yaitu Range $=(\mathrm{Xt}-\mathrm{Xr})+1$

Keterangan:

$\Sigma \mathrm{fX}=$ Jumlah responden yang memilih (frekuensi) x nilai tengah setiap interval.

$\mathrm{N} \quad=$ Jumlah responden

$\mathrm{M}=$ Mean

$\mathrm{SD}=$ Standar Deviasi

Range $=$ Rentangan dari skor

$\mathrm{Xt}=$ Skor Tertinggi

$\mathrm{Xr} \quad=$ Skor Terendah

Setelah data diolah menggunakan rumus statistik kemudian ditetapkan kriteria penilaian masing-masing data yang diperoleh yang 
mengacu kepada batasan yang dikemukakan oleh Anas Sudijono (2009: 329): diberikan perlakuan. Maka dapat diuraikan hasil penelitian sebagai berikut:
Tabel

\section{Kriteria Pengolahan Data Deskriptif Hasil Penelitian}

\begin{tabular}{|l|c|}
\hline Kriteria & Skor \\
\hline Sangat Tinggi & $\geq$ Mean $+1,5$ SD \\
\hline Tinggi & $\begin{array}{c}\geq \text { Mean }+0,5 \text { SD } \\
\text { s/d }<\text { Mean }+1,5 \text { SD }\end{array}$ \\
\hline Sedang & $\begin{array}{c}\geq \text { Mean-0,5 SD } \\
\text { s/d }<\text { Mean }+0,5 \text { SD }\end{array}$ \\
\hline Rendah & $\geq$ Mean-1,5 SD \\
& s/d $<$ Mean-0,5 SD \\
\hline Sangat Rendah & $<$ Mean-1,5 SD \\
\hline
\end{tabular}

Untuk melihat perbedaan kontrol diri siswa antara sebelum dan sesudah diberi perlakuan dengan layanan informasi dengan metode problem solving, dilakukanlah analisis data dengan menggunakan metode teknik statistik non parametrik yaitu: Wilcoxon Signed Ranks Test, menggunakan rumus yang dikemukakan oleh Wahid Sulaiman (2003 : 79) :

$$
\mathrm{Z}=\frac{T-\mu T}{\sigma T}
$$

Keterangan :

$$
\begin{array}{ll}
\mathrm{T} & =\text { jumlah responden } \\
\text { HT } & =\text { mean } \\
\text { бT } & =\text { deviasi standar }
\end{array}
$$

Sedangkan untuk melihat perbedaan kontrol diri siswa antara kelompok eksperimen yang diberi perlakuan (layanan informasi dengan metode problem solving) dengan kelompok kontrol yang tidak di beri perlakuan. dilakukanlah analisis data dengan menggunakan metode teknik statistik non parametrik yaitu: Test Kolmogorov-Smirnov dua sampel, yaitu dengan menggunakan program SPSS versi 20 .

\section{HASIL DAN PEMBAHASAN}

\section{Hasil}

Berdasarkan hasil pengolahan data yang sesuai tujuan penelitian yaitu untuk: 1) Mengungkapkan perbedaan kontrol diri siswa pada kelompok eksperimen sebelum dan setelah diberikan perlakuan layanan informasi dengan metode problem solving. 2) Mengungkapkan perbedaan kontrol diri siswa kelompok kontrol tanpa perlakuan layanan informasi dengan metode problem solving. 3) Mengungkapkan perbedaan kontrol diri siswa kelompok eksperimen yang diberikan perlakuan layanan informasi dengan metode problem solving dengan siswa kelompok kontrol yang tidak
Perbedaan Kontrol Diri Siswa Kelompok Eksperimen Pada Pretest dan Posttest Setelah Dilaksanakan Layanan Informasi dengan Metode Problem Solving

\begin{tabular}{|c|c|c|c|c|c|c|c|}
\hline \multirow{3}{*}{$\begin{array}{l}\mathrm{N} \\
\mathrm{O}\end{array}$} & \multirow{3}{*}{$\begin{array}{c}\text { Kode } \\
\text { Respon } \\
\text { den }\end{array}$} & \multicolumn{6}{|c|}{ Eksperimen } \\
\hline & & \multicolumn{3}{|c|}{ Pretest } & \multicolumn{3}{|c|}{ Postest } \\
\hline & & Skor & $\%$ & $\begin{array}{l}\text { Kate } \\
\text { gori }\end{array}$ & Skor & $\%$ & $\begin{array}{l}\text { Kate } \\
\text { gori }\end{array}$ \\
\hline 1 & $\mathrm{AA}$ & 135 & 79,41 & $\mathrm{~T}$ & 140 & 82,35 & ST \\
\hline 2 & ASP & 127 & 74,71 & SD & 132 & 77,65 & $\mathrm{~T}$ \\
\hline 3 & BA & 132 & 77,65 & $\mathrm{~T}$ & 153 & 90 & $\mathrm{ST}$ \\
\hline 4 & DRT & 126 & 74,12 & SD & 134 & 78,82 & $\mathrm{~T}$ \\
\hline 5 & DF & 119 & 70 & SD & 132 & 77,65 & $\mathrm{~T}$ \\
\hline 6 & FRA & 114 & 67,06 & $\mathrm{R}$ & 118 & 69,41 & SD \\
\hline 7 & FAP & 136 & 80 & $\mathrm{~T}$ & 151 & 88,82 & ST \\
\hline 8 & FG & 97 & 57,06 & SR & 119 & 70 & SD \\
\hline 9 & FSP & 122 & 71,76 & $\mathrm{SD}$ & 136 & 80 & $\mathrm{~T}$ \\
\hline 10 & HPD & 106 & 62,35 & $\mathrm{R}$ & 122 & 71,76 & SD \\
\hline 11 & HS & 114 & 67,06 & $\mathrm{R}$ & 131 & 77,06 & $\mathrm{~T}$ \\
\hline 12 & IZ & 117 & 68,82 & SD & 136 & 80 & $\mathrm{~T}$ \\
\hline 13 & IUS & 133 & 78,24 & $\mathrm{~T}$ & 142 & 83,53 & ST \\
\hline 14 & $\mathrm{KN}$ & 122 & 71,76 & SD & 130 & 76,47 & $\mathrm{~T}$ \\
\hline 15 & MDA & 118 & 69,41 & SD & 129 & 75,88 & $\mathrm{~T}$ \\
\hline 16 & MGD & 135 & 79,41 & $\mathrm{~T}$ & 149 & 87,65 & ST \\
\hline 17 & MIR & 125 & 73,53 & SD & 131 & 77,06 & $\mathrm{~T}$ \\
\hline 18 & MRA & 120 & 70,59 & SD & 132 & 77,65 & $\mathrm{~T}$ \\
\hline 19 & NPM & 126 & 74,12 & SD & 131 & 77,06 & $\mathrm{~T}$ \\
\hline 2 & NY & 99 & 58,24 & SR & 125 & 73,53 & $\mathrm{SD}$ \\
\hline 21 & NW & 121 & 71,18 & SD & 137 & 80,59 & $\mathrm{~T}$ \\
\hline 22 & RAN & 114 & 67,06 & $\mathrm{R}$ & 127 & 74,71 & SD \\
\hline 23 & RAP & 129 & 75,88 & $\mathrm{~T}$ & 148 & 87,06 & ST \\
\hline 24 & RO & 123 & 72,35 & SD & 128 & 75,29 & $\mathrm{~T}$ \\
\hline 25 & SMR & 127 & 74,71 & SD & 129 & 75,88 & $\mathrm{~T}$ \\
\hline & mlah & 3037 & 1786 & & 3342 & 1966 & \\
\hline & Iean & $\begin{array}{c}121, \\
48\end{array}$ & 71,46 & SD & 155 & 91,18 & ST \\
\hline
\end{tabular}

Tabel 1

Hasil Pretest dan Posttest Kontrol Diri Siswa Kelompok Eksperimen

Berdasarkan data pretest dan posttest yang dapat dilihat pada tabel 2 diketahui bahwa 
terjadi peningkatan kontrol diri pada keseluruhan siswa dari kelompok eksperimen, ini berarti dari data pretest dan posttest yang diperoleh diketahui bahwa terjadi peningkatan kontrol diri siswa pada kelompok eksperimen setelah diberikan layanan informasi dengan metode problem solving. Perbedaan hasil pretest dan posttest kontrol diri siswa juga dapat dilihat pada grafik di bawah ini.

\section{Grafik 2}

Perbedaan Hasil Pretest dan Posttest Kontrol Diri Siswa Kelompok Eksperimen

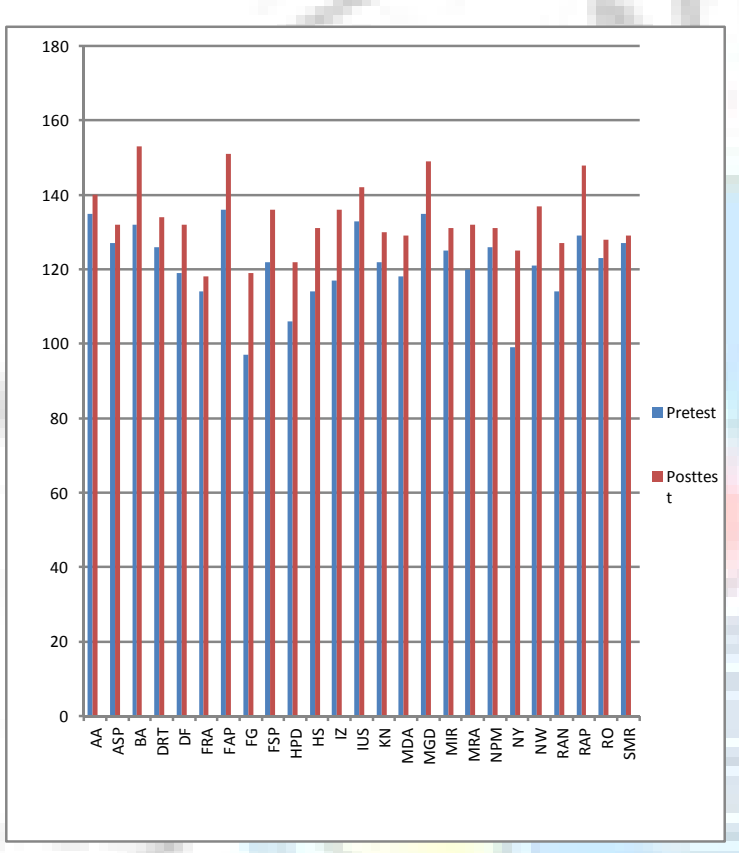

Berdasarkan grafik di atas, dapat dilihat bahwa terdapat peningkatan secara keseluruhan hasil pretest dan posttest siswa pada kelompok eksperimen yang dilaksanakan layanan informasi dengan metode problem solving.
Perbedaan Kontrol Diri Siswa Kelompok Kontrol Pada Pretest dan Posttest Tanpa Dilaksanakan Layanan Informasi dengan Metode Problem Solving

Tabel 2

Hasil Pretest dan Posttest Kontrol Diri Siswa Kelompok Kontrol

\begin{tabular}{|c|c|c|c|c|c|c|c|}
\hline \multirow[t]{3}{*}{ NO } & \multirow{3}{*}{$\begin{array}{c}\text { Kode } \\
\text { Respon } \\
\text { den }\end{array}$} & \multicolumn{6}{|c|}{ Kontrol } \\
\hline & & \multicolumn{3}{|c|}{ Pretest } & \multicolumn{3}{|c|}{ Postest } \\
\hline & & Skor & $\%$ & $\begin{array}{l}\text { Kate } \\
\text { gori }\end{array}$ & Skor & $\%$ & $\begin{array}{l}\text { Kate } \\
\text { gori }\end{array}$ \\
\hline 1 & AS & 131 & 77,1 & $\mathrm{~T}$ & 118 & 69,41 & SD \\
\hline 2 & BP & 122 & 71,8 & SD & 114 & 67,06 & SD \\
\hline 3 & DB & 132 & 77,6 & $\mathrm{~T}$ & 139 & 81,76 & ST \\
\hline 4 & $\mathrm{FH}$ & 120 & 70,6 & SD & 109 & 64,12 & SD \\
\hline 5 & FHS & 119 & 70 & SD & 80 & 47,06 & SR \\
\hline 6 & FZ & 114 & 67,1 & $\mathrm{R}$ & 121 & 71,18 & $\mathrm{~T}$ \\
\hline 7 & HP & 126 & 74,1 & $T$ & 86 & 50,59 & $\mathrm{R}$ \\
\hline 8 & $\mathrm{HQ}$ & 107 & 62,9 & SR & 138 & 81,18 & ST \\
\hline 9 & IB & 123 & 72,4 & SD & 105 & 61,76 & SD \\
\hline 10 & MA & 112 & 65,9 & $\mathrm{R}$ & 116 & 68,24 & SD \\
\hline 11 & $\mathrm{MB}$ & 117 & 68,8 & $\mathrm{R}$ & 110 & 64,71 & SD \\
\hline 12 & $\mathrm{MHA}$ & 111 & 65,3 & $R$ & 80 & 47,06 & SR \\
\hline 13 & MID & 127 & 74,7 & $T$ & 127 & 74,71 & $\mathrm{~T}$ \\
\hline 14 & MRB & 119 & 70 & SD & 123 & 72,35 & $\mathrm{~T}$ \\
\hline 15 & MRF & 122 & 71,8 & SD & 97 & 57,06 & $\mathrm{R}$ \\
\hline 16 & $\mathrm{NF}$ & 128 & 75,3 & $T$ & 106 & 62,35 & SD \\
\hline 17 & NFR & 119 & 70 & SD & 121 & 71,18 & $\mathrm{~T}$ \\
\hline 18 & RW & 120 & 70,6 & SD & 80 & 47,06 & $S R$ \\
\hline 19 & RY & 124 & 72,9 & SD & 139 & 81,76 & ST \\
\hline 20 & SM & 103 & 60,6 & SR & 104 & 61,18 & SD \\
\hline 21 & SWD & 121 & 71,2 & SD & 114 & 67,06 & SD \\
\hline 22 & $\mathrm{SQ}$ & 111 & 65,3 & $\mathrm{R}$ & 101 & 59,41 & SD \\
\hline 23 & $\mathrm{TM}$ & 126 & 74,1 & $T$ & 94 & 55,29 & $\mathrm{R}$ \\
\hline & TR & 118 & 69,4 & SD & 104 & 61,18 & SD \\
\hline & YRP & 124 & 72,9 & SD & 113 & 66,47 & SD \\
\hline Jum & & 2996 & 1556 & & 2739 & 1611 & \\
\hline Mea & & $\begin{array}{c}119 \\
84\end{array}$ & $\begin{array}{c}62,2 \\
4\end{array}$ & SD & $\begin{array}{c}109 \\
56\end{array}$ & 64,45 & SD \\
\hline
\end{tabular}


Berdasarkan data pretest dan posttest yang terlihat pada tabel 3 diketahui bahwa terjadi peningkatan kontrol diri siswa pada sepuluh orang dari dua puluh lima siswa dalam kontrol diri pada kelompok kontrol, sembilan orang tidak mengalami peningkatan pada kontrol dirinya, sedangkan pada enam orang siswa lainnya mengalami penurunan tingkat kontrol diri, itu berarti dari data tersebut dapat diketahui bahwa tidak semua siswa anggota kelompok kontrol mengalami peningkatan pada kontrol diri. Perbedaan hasil pretest dan posttest kontrol diri siswa pada kelompok kontrol juga dapat dilihat pada grafik di bawah ini:

\section{Grafik 2}

Perbedaan Hasil Pretest dan Posttest Kontrol Diri Siswa Kelompok Kontrol

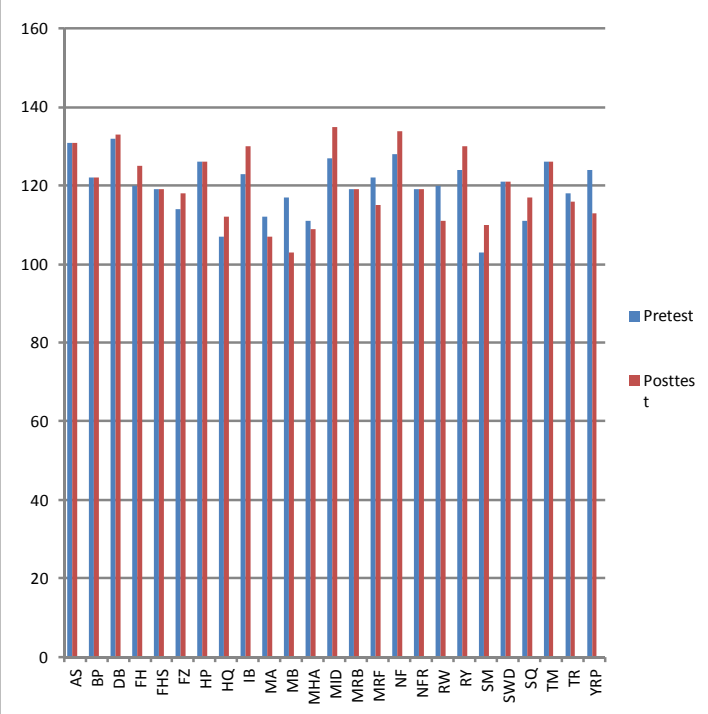

Berdasarkan grafik di atas dapat dilihat bahwa tidak terdapat peningkatan secara keseluruhan pada siswa kelompok kontrol pada hasil pretest dan posttest tanpa dilaksanakan layanan informasi dengan metode problem solving.

\section{Perbedaan Peningkatan Kontrol Diri Siswa Pada Kelompok Eksperimen dengan Kelompok Kontrol}

Tabel 3

Hasil Pretest dan Posttest Kelompok

Eksperimen dengan Kelompok Kontrol

\begin{tabular}{|c|c|c|c|c|c|c|}
\hline \multirow[t]{2}{*}{ NO } & \multirow{2}{*}{$\begin{array}{c}\text { Kode } \\
\text { Respon } \\
\text { den }\end{array}$} & \multicolumn{2}{|c|}{ Eksperimen } & \multirow{2}{*}{$\begin{array}{c}\text { Kode } \\
\text { Respon } \\
\text { den }\end{array}$} & \multicolumn{2}{|c|}{ Kontrol } \\
\hline & & Pretest & Posttest & & Pretest & Postest \\
\hline 1 & AA & 135 & 140 & AS & 131 & 131 \\
\hline 2 & ASP & 127 & 132 & $\mathrm{BP}$ & 122 & 122 \\
\hline 3 & BA & 132 & 153 & DB & 132 & 133 \\
\hline 4 & DRT & 126 & 134 & $\mathrm{FH}$ & 120 & 125 \\
\hline 5 & DF & 119 & 132 & FHS & 119 & 119 \\
\hline 6 & FRA & 114 & 118 & $\mathrm{FZ}$ & 114 & 118 \\
\hline 7 & FAP & 136 & 151 & HP & 126 & 126 \\
\hline 8 & FG & 97 & 119 & $\mathrm{HQ}$ & 107 & 112 \\
\hline 9 & FSP & 122 & 136 & IB & 123 & 130 \\
\hline 10 & HPD & 106 & 122 & MA & 112 & 107 \\
\hline 11 & $\mathrm{HS}$ & 114 & 131 & $\mathrm{MB}$ & 117 & 103 \\
\hline 12 & IZ & 117 & 136 & $\mathrm{MHA}$ & 111 & 109 \\
\hline 13 & IUS & 133 & 142 & MID & 127 & 135 \\
\hline 14 & $\mathrm{KN}$ & 122 & 130 & MRB & 119 & 119 \\
\hline 15 & MDA & 118 & 129 & MRF & 122 & 115 \\
\hline 16 & MGD & 135 & 149 & $\mathrm{NF}$ & 128 & 134 \\
\hline 17 & MIR & 125 & 131 & NFR & 119 & 119 \\
\hline 18 & MRA & 120 & 132 & RW & 120 & 111 \\
\hline 19 & NPM & 126 & 131 & RY & 124 & 130 \\
\hline 20 & NY & 99 & 125 & SM & 103 & 110 \\
\hline 21 & NW & 121 & 137 & SWD & 121 & 121 \\
\hline 22 & RAN & 114 & 127 & SQ & 111 & 117 \\
\hline 23 & RAP & 129 & 148 & TM & 126 & 126 \\
\hline 24 & RO & 123 & 128 & $\mathrm{TR}$ & 118 & 116 \\
\hline 25 & SMR & 127 & 129 & YRP & 124 & 113 \\
\hline \multicolumn{2}{|c|}{ Jumlah } & 2143 & 2365 & & 2144 & 2175 \\
\hline \multicolumn{2}{|c|}{ Mean } & $\begin{array}{c}164.84 \\
6 \\
\end{array}$ & 181.92 & & 164.92 & 167.31 \\
\hline \multicolumn{2}{|c|}{ Kategori } & $\mathrm{CB}$ & B & & $C B$ & $\mathrm{CB}$ \\
\hline
\end{tabular}

Berdasarkan data pretest dan posttest yang dapat dilihat pada tabel 4 diketahui bahwa terjadi peningkatan kontrol diri siswa setelah diberikan layanan informasi dengan metode problem solving pada kelompok eksperimen, namun perbedaan peningkatan kontrol diri pada 
kelompok eksperimen lebih besar dibandingkan perbedaan peningkatan pada kelompok kontrol. Selain itu dari tabel dapat dilihat bahwa hampir keseluruhan siswa pada kelompok eksperimen mengalami peningkatan setelah diberikan layanan infromasi dengan metode problem solving, sedangkan pada kelompok kontrol masih terdapat beberapa siswa yang tidak mengalami peningkatan pada kontrol diri. Itu berarti bahwa pemberian layanan informasi dengan metode problem solving lebih efektif dalam meningkatkan kontrol diri siswa.

\section{Pembahasan}

Pembahasan hasil temuan penelitian yang dapat diuraikan sebagai berikut:

Perbedaan Kontrol Diri Siswa Kelompok Eksperimen Pada Pretest dan Posttest Setelah Dilaksanakan Layanan Informasi dengan Metode Problem Solving

Hipotesis pertama yang berbunyi "Terdapat perbedaan pada kontrol diri siswa pada pretest dan posttest kelompok eksperimen". Hipotesis tersebut diuji dengan menggunakan Wilcoxon Signed Rank Test dengan menggunakan program SPSS versi 20. terlihat bahwa angka probabilitas Asymp. Sig.(2tailed) kontrol diri pada kelompok eksperimen sebesar 0.000 , atau probabilitas dibawah alpha 0,05 dari hasil tersebut maka Ho ditolak dan Hi diterima. Dengan demikian maka hipotesis pertama yang diuji dalam penelitian dapat diterima, yaitu "Terdapat perbedaan yang signifikan pada kontrol diri siswa pada kelompok eksperimen".

Berdasarkan hasil penelitian yang dilakukan melalui eksperimen dengan topik sebuah masalah yang berkenaan dengan kontrol diri, ternyata kontrol diri siswa kelompok eksperimen secara keseluruhan menunjukkan adanya perbedaan secara signifikan antara sebelum dan sesudah mengikuti layanan informasi dengan metode problem solving. Hal tersebut berarti adanya pengaruh dari kegiatan layanan informasi dengan metode problem solving.Berdasarkan hasil penelitian yang dilakukan melalui eksperimen dengan materi tentang masalah yang berkaitan dengan kontrol diri, ditemukan bahwa peningkatan kontrol diri siswa yang mengikuti layanan informasi dengan metode problem solving kelompok eksperimen hampir secara keseluruhan menunjukkan adanya perbedaan secara signifikan antara sebelum dan sesudah mengikuti layanan informasi dengan metode problem solving. Hal tersebut berarti adanya pengaruh dari kegiatan layanan informasi dengan metode problem solving.

Pemberian layanan informasi dengan menggunakan metode problem solving menuntut siswa untuk lebih aktif berpendapat pada saat kegiatan berlangsung. Siswa juga dituntut aktif untuk mampu berpikir seacara ilmiah dalam memecahkan masalah yang menjadi topik pembahasan. Dengan demikian maka kontrol siswa dalam mengikuti layanan informasi dengan menggunakan metode problem solving mengalami peningkatan secara keseluruhan pada kelompok eksperimen.

Hal ini senada dengan yang dikemukakan oleh Wina Sanjaya (2006: 220) keunggulan metode problem solving yaitu dapat menantang kemampuan siswa dan dapat meningkatkan aktivitas pembelajaran siswa. Dengan demikian siswa akan terlibat aktif pada proses pembelajaran dan hal ini juga akan meningkatkan kontrol diri siswa dalam belajar. Karena kontrol diri siswa juga dipengaruhi oleh suasana hati siswa pada saat mengikuti pembelajaran. Sebagaimana dikemukakan oleh Goleman (1997:75) bahwa suasana hati adalah inti dari hubungan sosial yang baik. Apabila seseorang terampil dalam menyesuaikan diri dengan suasana hati, maka dia akan mampu mengontrol diri.

Prayitno (2012:50) juga mengemukakan bahwa "tujuan umum layanan informasi (INFO) adalah dikuasainya informasi tertentu oleh peserta layanan. Informasi tersebut selanjutnya digunakan oleh peserta untuk keperluan hidupnya sehari-hari (dalam rangka kehidupan efektif sehari-hari---KES) dan perkembangan dirinya". Dengan diadakannya layanan informasi dengan metode problem solving dengan materi yang berkenaan dengan permasalahan yang berkaitan dengan kontrol diri siswa agar dapat siswa dapat mengontrol perilakunya, serta mandiri untuk memecahkan permasalahan yang dihadapinya. Sejalan dengan hal di atas, Hein Kock (1995:101) menjelaskan bahwa "penyampaian layanan informasi dapat digunakan cara salah satunya yaitu memecahkan masalah (problem solving) merupakan cara penyampaian materi dimana siswa dimandirikan untuk memecahkan masalah melalui tugas yang diberikan oleh guru bimbingan dan konseling sesuai dengan topik yang dibahas".

Perbedaan Kontrol Diri Siswa Kelompok Kontrol Pada Pretest dan Posttest Tanpa Dilaksanakan Layanan Informasi dengan Metode Problem Solving

Hasil uji hipotesis kedua yang menyatakan "tidak terdapat perbedaan pada kontrol diri siswa pada pretest dan posttest kelompok kontrol". Hipotesis tersebut diuji dengan menggunakan Wilcoxon Signed Rank Test dengan menggunakan program SPSS versi 20. terlihat bahwa angka probabilitas Asymp. 
Sig.(2-tailed) kontrol diri siswa pada kelompok kontrol sebesar 0,204 atau probabilitas di atas alpha 0,05 dari hasil tersebut maka Ho diterima dan Hi ditolak. Dengan demikian maka hipotesis kedua yang diuji dalam penelitian dapat diterima, yaitu "tidak terdapat perbedaan yang signifikan pada kontrol diri siswa pada kelompok kontrol".

Berdasarkan analisis data hasil penelitian perbedaan dari pretest dan posttest dari kelompok kontrol yang berjumlah 25 orang siswa terdapat 10 orang yang mengalami peningkatan kontrol diri. Sedangkan yang mengalami penurunan terdapat 7 orang siswa dan yang tidak terdapat perubahan yaitu 8 orang siswa. Perubahan yang terjadi pada kelas kontrol terjadi dikarenakan siswa tidak mendapatkan perlakuan khusus yaitu layanan informasi dengan metode problem solving melainkan hanya mendapatkan layanan dari guru bimbingan dan konseling di sekolah saja.

Terdapatnya peningkatan dan penurunan kontrol diri pada beberapa orang siswa kelompok kontrol disebabkan oleh pemanfaatan metode pemecahan masalah yang dilakukan oleh guru BK secara spontanitas, hal ini disebabkan oleh guru BK telah mengetahui metode-metode layanan informasi pada saat di perguruan tinggi, sehingga metode pemecahan masalah itu keluar tanpa disadari. Sebagaimana dikemukakan oleh (Hein Kock 1995:101) penyampaian layanan informasi dapat digunakan cara yaitu: 1) ceramah, 2) tanya jawab, 3) kerja kelompok, 4) diskusi kelas, 5) pemecahan masalah.

Penerapan cara pemecahan masalah yang diberikan oleh guru BK pada kelompok kontrol berskala kecil, tidak terfokus, tidak dilakukan secara terus-menerus, hanya bersifat spontanitas membuat kelompok kontrol tetap mengalami peningkatan pada kontrol dirinya dalam belajar. Namun, metode pemecahan masalah yang diterapkan pada kelompok kontrol tidak di design sebegitu rupa. Selain itu, peningkatan ini juga dapat dijelaskan dari sudut pesertanya sendiri karena pengaruh tuntutan teknologi dan minat karir masa depan mereka. Dengan demikian terlihat bahwa kontrol diri siswa kelompok kontrol secara keseluruhan tidak mengalami perubahan.

\section{Perbedaan Peningkatan Kontrol Diri Siswa Pada Kelompok Eksperimen dengan Kelompok Kontrol}

Hipotesis ketiga yang berbunyi "Terdapat perbedaan pada kontrol diri siswal antara kelompok eksperimen dan kelompok kontrol". Hipotesis tersebut diuji dengan menggunakan Two Sample Kolmogorov-Smirnov Test menggunakan program SPSS versi 20. terlihat bahwa penalaran moralsiswa pada kolom
Asymp.sig. (2-tailed)/significance untuk uji dua sisi adalah 0.000. Maka Ho ditolak dan Hi diterima. Ini berarti bahwa terdapat perbedaan yang signifikan pada kontrol diri siswa antara kelompok kontrol yang tidak mendapatkan perlakuan dengan kelas eksperimen yang mendapatkan perlakuan (layanan informasi dengan metode problem solving). Dengan demikian hipotesis ketiga menyatakan "terdapat perbedaan yang signifikan pada kontrol diri siswa antara posttest kelompok eksperimen dengan posttest kelompok kontrol" diterima.

Terdapatnya perbedaan dari hasil hasil posttest kedua kelompok ini salah satunya disebabkan oleh perlakuan yang diberikan pada masing-masing kelompok. Layanan informasi dengan metode problem solving merupakan layanan yang lebih efektif dalam meningkatkan kontrol diri siswa. Layanan informasi dengan metode problem solving membantu siswa untuk berpikir dalam memecahkan suatu masalah yang dijadikan topik dalam layanan informasi. Sebagaimana dikemukakan oleh Tohirin (2007:147) bahwa "layanan informasi bertujuan agar individu memahami berbagai informasi untuk mencegah timbulnya suatu masalah, pemecahan suatu masalah, dan untuk memelihara serta mengembangkan potensi individu agar dapat mengaktualisasikan hakhaknya sehingga tercipta kemandirian".

Layanan informasi adalah bagian dari salah satu layanan dalam bimbingan dan konseling yang diberikan kepada siswa untuk menambah wawasan siswa terhadap suatu hal yang bermanfaat untuk mengenali diri seperti pertumbuhan tubuh, mengembangkan sikap dan kebiasaan belajar (Prayitno, 2004:6).

Oleh karena itu, guru bimbingan dan konseling dalam memberikan layanan informasi dapat memilih dan menetapkan metode yang tepat agar dapat menumbuhkan semangat siswa dalam mengikuti layanan informasi yang diberikan dan tercapainya tujuan yang diharapkan. Sebagaimana dikemukakan oleh Abdul Aziz Wahab (2007: 87) metode yang dipilih dianggap paling tepat ditinjau dari sudut pertimbangan guru baik sebagai intelektual maupun sebagai guru. Metode mengajar merupakan cara yang digunakan guru untuk mencapai tujuan pembelajaran. Dalam memilih metode mengajar guru diharapkan memilih metode yang tepat sesuai dengan keadaan siswa, dukungan terhadap pelajaran dan juga dari segi intelektual guru.

Hal senada juga dikemukakan oleh Benny A. Pribadi (2009:42) menjelaskan bahwa "metode pembelajaran merupakan proses atau prosedur yang digunakan oleh guru atau instruktur untuk mencapai tujuan atau kompetensi". Oleh karena itu pemilihan metode pembelajaran perlu didasarkan pada kesesuaian 
dengan tugas dan tujuan pembelajaran yang akan ditempuh oleh siswa. Terutama dalam penyampaian informasi hendaklah menggunakan metode yang menarik untuk menciptakan kegiatan pembelajaran yang efektif.

Metode problem solving (pemecahan masalah) merupakan metode yang dapat membantu siswa untuk mampu berpikir kritis dan berani mengemukakan pendapatnya. Metode problem solving menarik siswa untuk berperan aktif dalam proses pembelajaran. Sebagaimana dikemukakan oleh Wina Sanjaya (2006: 220) metode problem solving (pemecahan masalah) dianggap lebih menyenangkan dan lebih disuaki siswa. Sehingga siswa tertarik untuk berpikir dan menambah pengetahuan baru bagi siswa.

Dengan demikian, layanan informasi dengan metode problem solving membantu peserta didik dalam pengembangan pribadi, kemampuan hubungan sosial, kegiatan belajar, karir/jabatan, dan pengambilan keputusan, serta melakukan kegiatan tertentu melalui kegiatan kelas yang beranggotakan sekitar 25 orang. Dan dengan kegiatan ini diharapkan dapat meningkatkan kontrol diri siswa terutama kontrol diri siswa dalam belajar.

\section{KESIMPULAN DAN SARAN}

\section{Kesimpulan}

Berdasarkan temuan dari penelitian ini yaitu:(1) terdapat perbedaan yang signifikan pada kontrol diri siswa sebelum dan sesudah mengikuti layanan informasi dengan metode problem solving pada kelompok eksperimen, (2) tidak terdapat perbedaan yang signifikan pada kontrol diri siswa pada kelompok kontrol, (3) terdapat perbedaan yang signifikan pada kontrol diri siswa pada kelompok eksperimen dengan kelompok kontrol tanpa diberi layanan informasi dengan metode problem solving.

2. Saran

a. Guru Bimbingan dan Konseling, untuk terus meningkatkan dan mengembangkan layanan bimbingan dan konseling terutama layanan informasi dengan metode problem solving untuk meningkatkan kontrol diri siswa.

b. Kepala sekolah MTsN Lubuk Buaya Padang, untuk lebih memperhatikan layanan bimbingan dan konseling terutama dalam penyediaan dan pengadaan sarana belajar umumnya seperti fasilitas dan waktu yang dibutuhkan guru bimbingan dan konseling dalam membantu mengembangkan kompetensi siswa dan mendorong guru bimbingan dan konseling untuk melaksanakan layanan informasi. c. Kepala Dinas Pendidikan Provinsi Sumatera Barat, untuk meningkatkan kinerja guru pembimbing dengan memberikan pelatihan-pelatihan yang bertujuan untuk meningkatkan kompetensi guru pembimbing.

d. Dosen Jurusan Bimbingan dan Konseling Fakultas Ilmu Pendidikan Universitas Negeri Padang, sebagai bahan evaluasi serta mempersiapkan bahan dalam rancangan program bimbingan dan konseling. Serta untuk lebih meningkatkan kualitas mahasiswa sebagai calon guru bimbingan dan konseling agar dapat memberikan pelayanan terbaik kepada peserta didik, khususnya dalam memberikan layanan informasi.

e. Bagi peserta didik yang telah mengikuti layanan informasi dengan metode problem solving diharapkan dapat meningkatkan kontrol dirinya dalam belajar dan agar tidak bosan untuk mengikuti kegiatan kegiatan yang dilakukan oleh guru bimbingan dan konseling.

f. Bagi peneliti selanjutnya diharapkan dapat melanjutkan penelitian dengan jenis layanan bimbingan dan konseling yang lainnya.

\section{KEPUSTAKAAN}

Anas Sudijono. 2009. Pengantar Evaluasi Pendidikan. Jakarta: Raja Grafindo Persada.

Abdul Aziz Wahab. 2007. Model dan Model Mengajar. Bandung: Alfabeta

Benny A. Pribadi. 2009. Model Desain Sistem Pembelajaran. Jakarta: Dian Rakyat

Daryanto. 2010. Belajar dan Mengajar. Bandung: CV Yrama Widya

Hein Kock. 1995. Saya Guru yang Baik. Yogyakarta: Kanisius

Nana Sudjana. 2011. Dasar-dasar Proses Belajar Mengajar. Bandung: Sinar Baru Algesindo

Prayitno dan Erman Amti. 2004. Dasar-Dasar Bimbingan dan Konseling. Jakarta: Rineka Cipta.

Prayitno. 1997. Pelayanan bimbingan dan konseling (seri pemandu pelaksanaan bimbingan konseling di SMP). Padang: BK FIP UNP. 
Tohirin. 2009. Bimbingan dan Konseling di Sekolah dan Madrasah. Jakarta: Rajawali

Tulus Winarsunu. 2002. Statistik dalam Penelitian Psikologi\&Pendidikan. Malang: UMM.
W.S Winkel. 1997. Bimbingan dan Konseling di Institusi Pendidikan. Jakarta: Gramedia Widiasarana

Wayan Nurkancana. 1993. Pemahaman Individu. Surabaya: Usaha Nasional

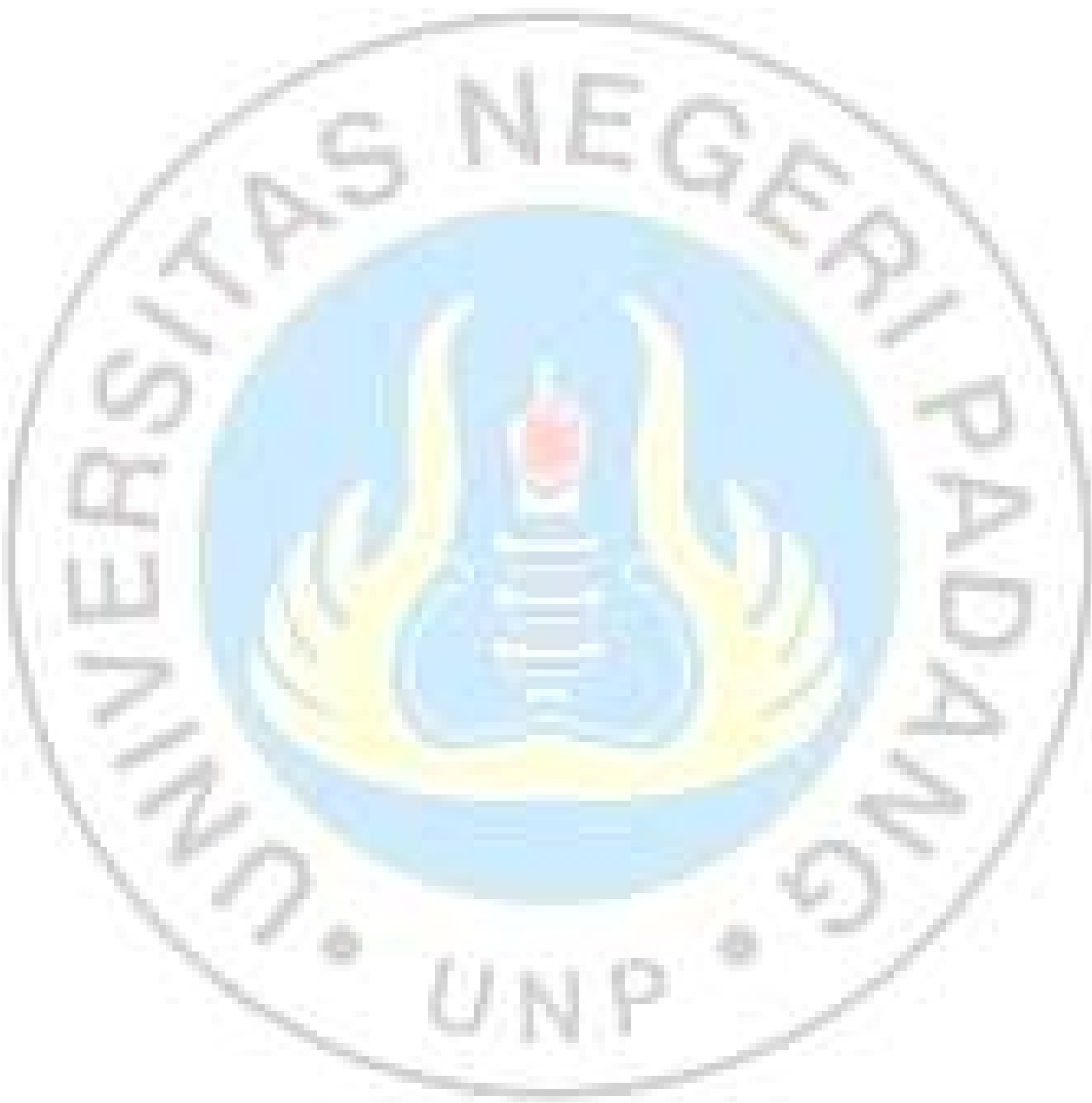

